\title{
Diversity of Amphibian Communities In Four Vegetation Types of Hidalgo State, Mexico
}

\author{
Uriel Hernández-Salinas* and Aurelio Ramírez-Bautista
}

\author{
Centro de Investigaciones Biológicas, Universidad Autónoma del Estado de Hidalgo, A.P. 1-69 Plaza Juárez, \\ C.P. 42001, Pachuca, Hidalgo, México
}

\begin{abstract}
The use of statistical tools to assess species richness in different biological groups has increased considerably in the recent years. In this context, during the wet and dry seasons of 2007 and 2008 (dry only), we evaluated the amphibian species richness (alpha and beta diversity) in four vegetation types: cloud forest (CF), pine-oak forest (POF), xeric scrub (XS), and tropical evergreen forest (TEF) in Hidalgo state, México. In this study, we sampled 16 sites in 9 months. The total species number recorded in the four vegetation types was 31. The CF was the vegetation type with the highest number of species. In contrast, the POF and the XS had the lowest alpha diversity. The POF had the highest number of exclusive species and the XS the lowest. The highest value of complementarity (beta diversity) was between the XS and the TEF. Our data reveals the conservation status of amphibian populations in different vegetation types in Hidalgo, and the high variation in species richness in each vegetation community suggests species habitat quality.
\end{abstract}

Keywords: Amphibians, Hidalgo, Species Richness, Diversity, Complementarity, Vegetation types.

\section{INTRODUCTION}

In recent years, regional species lists have more frequently been grounded in an explicit biogeographical and ecological context [1]. This has been the case for the distribution of amphibians, allowing a better approximation of the knowledge of species richness of this important animal group in many regions [2]. In the past 25 years, México has generated a significant amount of research on amphibians and reptiles, mainly focused on the distribution, species richness and higher-order diversity [2]. These efforts have revealed that at least 1204 species of amphibians and reptiles occur in México, one of the 12 megadiverse countries only after Brazil, Colombia and Australia [3]. Other authors indicate that richness of reptile species in Mexico is about 804 and 361 for amphibian species, occupying the second and fifth places worldwide, respectively [1].

In México, increased recognition of the diversity of its herpetofauna expanded the interest in biodiversity conservation, considering that this country is among the most diverse $[4,5]$. However, this species diversity is not evenly distributed taxonomically, since México contains a relatively high number of orders, families and genera of birds, mammals, amphibians and (non-avian) reptiles relative to other mega-diverse countries [6]. Amphibian diversity is clearly high in Mexico, and studies have constituted the basis of important scientific contributions [2]. Nevertheless, there are still some large areas of México in which little is known about their amphibian diversity [1]. One case is Hidalgo state, where existing data confirm the occurrence of

*Address correspondence to this author at the Centro de Investigaciones Biológicas, Universidad Autónoma del Estado de Hidalgo, A.P. 1-69 Plaza Juárez, C.P. 42001, Pachuca, Hidalgo, México; Tel: 52577172000 ext 6676; Fax: 5257717172 112; E-mail: uhernndez3@gmail.com amphibians in practically all vegetation types and elevations $[7,8]$, yet much of the state remains poorly surveyed.

Over the last few decades, many populations of amphibians in Hidalgo have decreased dramatically, mainly due to habitat destruction, for example, disturbance of forests, landscape fragmentation and pollution [9-11]. Other sources of decline include the targeted collection of certain species for the food or pet trades [12]. For example, the salamander Ambystoma velasci, the frogs Lithobates berlandieri and L. montezume have declined recently due to commercial exploitation as sources of meat, grease, oils, traditional medicines and pets $[13,14]$. Many people in Mexico, particularly in Hidalgo, eat amphibians because some species represent a good source of protein, and healthy populations of certain species (especially Lithobates spp.) often contain large numbers of individuals, which can be collected relatively easy and in large numbers. For example, large populations of the leopard frog (L. berlandieri) are killed for human consumption, and also for their skin, art, and souvenirs [15]. These negative factors have contributed to amphibian population declines worldwide [16-18].

Amphibian diversity in Hidalgo is threatened with exploitation by human consumption. For example, it is well known that $A$. velasci is a common food item in the diet of people living near their aquatic habitats, despite concerns on the long-term persistence of these wild populations [19, 20]. At present, there is some information on the distribution and species richness of amphibians and reptiles in some vegetation types in Hidalgo; however, with the high rate of destruction of many natural environments, the decrease of amphibian populations is dramatic [18, 21]. There are very few studies on the ecology of amphibians in Hidalgo, particularly those that address the current diversity and species richness of amphibians among vegetation communities. One of such studies [7] found that the species 


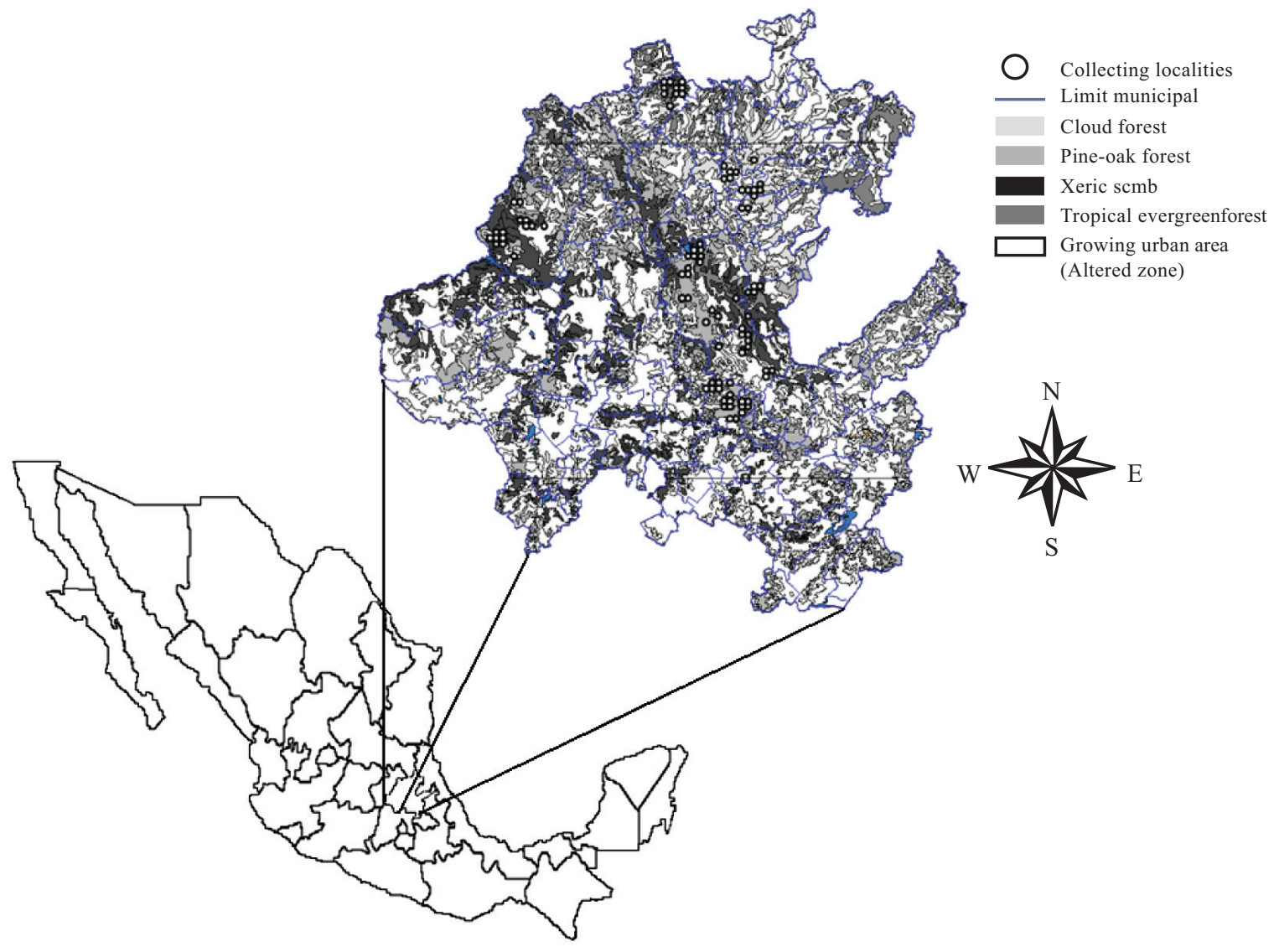

Fig. (1). Main vegetation types in the Hidalgo state, based on the nomenclature of [25]. The black points represent the sampling sites during the two seasons in the vegetation types.

richness was higher at higher elevations of cloud forest. [22] recorded a higher number of species in pine-oak forest than in the other vegetation types they examined. A study of arid tropical scrubland found reduced amphibian diversity relative to other vegetation types [23]. The limited data of amphibian richness in vegetation types points out that more information is needed in order to evaluate the current diversity of amphibians from Hidalgo, México.

The objective of this study is to identify patterns of alpha, beta and gamma diversity of amphibians present in four different vegetation types: cloud forest $(\mathrm{CF})$, pine-oak forest (POF), tropical evergreen forest (TEF), and xeric scrub (XS). These vegetation types represent an extensive area and a range of disturbances in Hidalgo.

\section{METHODS}

\subsection{Study Area}

Hidalgo state is located near the geographic center of México $\left(19^{\circ} 35^{`} 52^{\prime \prime}\right.$ to $21^{\circ} 25^{\prime} 00^{\prime \prime} \mathrm{N}, 97^{\circ} 57^{\prime} 27^{\prime \prime}$ to $99^{\circ}$ $\left.51^{\prime} 51^{\prime \prime} \mathrm{W}\right)$, with a mean elevation of $1660 \mathrm{~m}$ (18-3490 m.a.s.1) [24]. Within the state there are eight primary vegetation types from the ten recognized in México [25]. The four vegetation types selected in this study represent the more extensive vegetation types in the state (Fig. 1).

\subsubsection{Cloud Forest (CF)}

Hidalgo is the third state of Mexico with largest area of CF (212,595.54 ha), only after Oaxaca and Chiapas [25-28].
This vegetation type is found at elevations ranging from 500 to 1,400 or 2000 meters above sea level [m.a.s.1.; 25, 26]. Mean annual temperature is $15^{\circ} \mathrm{C}$ with a maximum of $22^{\circ} \mathrm{C}$. The CF consists of two floristic elements, one of temperate affinity and the other of tropical affinity; this combination of floristic elements is the result of a typical climate of humid and warm conditions [classified by 25,27 ]. The areas where this vegetation type develops have high moisture and a climatic type $C f$ (temperate climate with rain throughout the year), but also $C w$ (temperate climate subhumid with summer rains), Af (hot and humid climate with rains throughout the year), and $A w$ [hot and subhumid climate with summer rains, 29]. Soils of $\mathrm{CF}$ are characterized by their acidity and $\mathrm{pH}[4$ to $6 ; 26]$. Floristic composition includes mainly epiphytes, shrubs, grasses and ferns [25]. Epiphytic bromeliads are abundant, e.g. Tillandsia spp and Peperomia spp [25]. Here, epiphytic ferns reach their greatest diversity, for example, the genera Polypodium, Lycopodium and Selaginella [26], the most representative are the tree ferns (Cyatheaceae) such as Sphaeropteris horrida and the endangered species Cyathea mexicana [26].

\subsubsection{Pine-Oak Forest (POF)}

This vegetation type is distributed in the mountain range, mainly in the Sierra de Pachuca, $(469,594.45$ ha) [25]. The most common pine species from Sierra de Pachuca are Pinus rudis, $P$. teocote, $P$. patula, and $P$. montezumae. While species of the genus Quercus are $Q$. laurina, $Q$. affinis, $Q$. rugosa, Q. glabrecens, Q. crassifolia, and $Q$. frutex [22]. 
$[24,25]$ mention that in Mexico, oak forests occupy 5.5\% of the country's area and along with pine forests occupy $13.7 \%$. This vegetation type establishes pioneer species after a human disturbance. Species of the genus Pinus and Quercus regenerate relatively quick, so this vegetation type is considered resistant to human influence, provided disturbance is not too intense and prolonged. It develops in dry, semi-dry, and temperate climates; variations in precipitations and temperature are due to the differences in altitude among the plains, valleys, and mountains in the provinces of the Transmexican Volcanic Belt and the Mexican Central Highlands. The Sierra de Pachuca is an area where there is an important species richness of pines and oaks in the state, with a temperate climate $C w$ (temperate subhumid with summer rains). This climate has two variants, whose differences are due to the amount of moisture and rainy patterns $[25,29]$.

\subsubsection{Xeric Scrub (XS)}

This vegetation type is found at altitudes between 1000 and 2400 m.a.s.l. in Hidalgo [23]. The annual average temperature ranges from 12 to $28^{\circ} \mathrm{C}$. The most abundant genus of this vegetation type is Larrea [23, 25, 27, 29]. The xeric scrub has four to five well defined strata in which dominance is shared by several species of cactus and mesquite [25]. This community covers much of Hidalgo, and includes climbing plants, such as the vines Ipomoea sp. that grows on the genus Opuntia. On the other hand, the only epiphytic plant that becomes relatively abundant in this vegetation type is Tillandsia recurvada that inhabits shrubs and columnar cacti from Barranca of Metztitlán and Tolantongo, in Hidalgo, and in southern Tehuacan Valley, in
Puebla. Additionally, this species occurs in the arid lands of northern of Mexico (Chihahua, Coahuila, and Baja Calinfornia) [23, 25]. Lichens are also present in this vegetation type, mainly Psora spp and Parmelia spp; they occur on the surface of some rocks and can be associated with roots of trees or Opuntia sp., which provide water to lichens. Bryophytes and fungi are extremely rare in this vegetation type; however, fern genera such as Notholaema, Cheilanthes, Pellaea and Sellaginela occur in this vegetation type. These genera are related to an accumulation of moisture, usually in small rock crevices [26]. The climate type is defined as semi-warm $B s$ (dry or arid climate) and its mean annual temperature is $18.5^{\circ} \mathrm{C}$ with a maximum in June $[25,29]$.

\subsubsection{Tropical Evergreen Forest (TEF)}

This vegetation type is located in an area of 205, 024.20 ha of Hidalgo [25], (Fig 1). There are also patches of tropical deciduous forest in the state, but it is restricted to small areas in Metztitlan, between 600 to $1200 \mathrm{~m}$ in altitude and in small patches of the northeast region of the state. Based on the classification of [30], climate is mainly Am (savanna or forest with rainfall throughout the year), but also $A f$ (hot and humid weather with rain throughout the year) in more humid areas, and $C w$ (humid temperate climate with summer rainfall). The mean annual temperature of this vegetation type is $24.8^{\circ} \mathrm{C}$, with a maximum of $31.5^{\circ} \mathrm{C}$ in July and August, and a minimum of $15.4^{\circ} \mathrm{C}$ in January $[29,30]$. Flora is constituted by members of the genera Quercus, Salix, Populos, Platanus, and Taxodium [25]. It is also common Manilkara zapota (gum) and Dioscorea composita. The tropical rain forest is a complex vegetation community, in

Table 1. Surveys carried out throughout a year in the main vegetation types of Hidalgo state. The numbers below each month constitute the 16 samples made in each vegetation type: CF (cloud forest), POF (pine-oak forest), XS (xeric scrub), TEF (tropical evergreen forest)

\begin{tabular}{|c|c|c|c|c|c|c|c|c|}
\hline Season & \multicolumn{6}{|c|}{2007} & & \\
\hline Dry (March-May) & \multicolumn{2}{|c|}{ Mach } & \multicolumn{2}{|c|}{ April } & \multicolumn{2}{|c|}{ May } & & \\
\hline Surveys & 1 & 2 & 3 & 4 & 5 & 6 & & \\
\hline Vegetation types & $\mathrm{CF}$ & POF & XS & TEF & $\mathrm{CF}$ & POF & & \\
\hline Season & \multicolumn{8}{|c|}{2007} \\
\hline Rainy (June-September) & \multicolumn{2}{|c|}{ June } & \multicolumn{2}{|c|}{ July } & \multicolumn{2}{|c|}{ August } & \multicolumn{2}{|c|}{ September } \\
\hline Surveys & 1 & 2 & 3 & 4 & 5 & 6 & 7 & 8 \\
\hline Vegetation types & $\mathrm{CF}$ & $\mathrm{CF}$ & POF & POF & XS & XS & TEF & TEF \\
\hline Season & \multicolumn{2}{|c|}{2008} & & & & & & \\
\hline Dry (Mach-April) & Mach & April & & & & & & \\
\hline Surveys & 1 & 1 & & & & & & \\
\hline Vegetation types & XS & TEF & & & & & & \\
\hline
\end{tabular}


which the dominant evergreen trees are over $25 \mathrm{~m}$ tall. However, not all trees are evergreen, as some of them lose their leaves during dry season, which coincides with flowering time of trees.

\subsection{Sampling Methods}

Amphibians were collected through direct searches in the above mentioned vegetation types, including their habitats and microhabitats. We carried out 16 three-day surveys in nine months during both the dry (March-May 2007, March 2008) and rainy seasons (June-September 2007, Table 1). We performed the last sampling survey in March-April 2008 (dry season) in XS and TEF to get the same number of samples (four for each vegetation type). Each three-day survey was carried out by three persons during six hours (11:00 - 14:00 hrs and from 20:00 to 23:00 hrs). All vegetation types were selected in a random way, considering the major original vegetation coverage. We walked during the established hours recording the number of amphibian species and their abundance in each vegetation type [31-33].

This study was supported by the scientific collecting permit number SGPA/DGVS/02090/07 and SGPA/DGVS/ 03811/08 granted by the Subsecretaría de Gestión para la Protección Ambiental/Dirección General de Vida Silvestre.

Specimens were assigned to species by using dichotomous keys for each taxonomic group [34-39]. All collected specimens were deposited in the collection of amphibians and reptiles of the Biological Research Center of the Universidad Autónoma del Estado de Hidalgo (UAEH).

\subsection{Data Analysis}

A common statistical approach to evaluate plant and animal communities is the diversity index. Local diversity is described by alpha diversity $[\alpha, 40]$ and represents an estimate of all species within a given site. Beta diversity $(\beta)$ is an estimate of complementarity, and measures the number of shared and unique species between sites. The species diversity of all sites within a larger region is described by gamma diversity $(\gamma)[40,41]$. We have used different diversity indexes in order to estimate more accurately and comprehensively the species richness found in the four vegetation types studied.

To determine the maximum expected amphibian species richness in the four vegetation types, species accumulation curves were generated with EstimateS V.750 [42]. To infer whether the inventories were complete, we used Chao1 and Chao2 non-parametric estimators of species richness. We then assessed the degree of overlap of the curves of singletons (number of species represented by a single individual or present in one sample) and doubletons (two individuals of a species present in a single sample) [42].

Chao1 is an estimator based on the abundance of individuals belonging to a species in a sample, where $\mathbf{S}$ is the number of species in a sample, $\mathbf{A}_{\mathbf{1}}$ is the number of singletons, and $\mathbf{A}_{2}$ is the number of doubletons ( ${ }^{\mathrm{s}} \mathrm{Chao} 1=$ $\mathrm{S}_{\mathrm{obs}}+\mathrm{A}_{1} / 2 \mathrm{~A}_{2}$ ) [42-44].

Chao2 is a non-parametric estimator of incidence that requires frequency data for each species within the sample set. $\mathbf{L}$ is the number of species that occur only in one sample (singletons) and $\mathbf{M}$ is the species number that occurs in exactly two samples ( $\left.{ }^{\mathrm{S}} \mathrm{Chao} 2=\mathrm{S}_{\mathrm{obs}}+\mathrm{L}^{2} / 2 \mathrm{M}\right)$ [42-44].

Using estimates of abundance and incidence we can calculate the accumulation of species within a vegetation type based on sampling effort, and determine whether estimates of relative species diversity within each vegetation type are accurate.

Species abundance and evenness were analyzed in each vegetation type and amphibian community generating abundance-dominance or rank-abundance curves. To plot the rank-abundance curves we calculated the logarithm of the proportion of each species as: $p(n / N)$. Species were then ordered from most to least abundant $[44,45]$.

$\beta$ diversity was estimated as the complementarity of amphibian species between pairs of vegetation types [42]:

1. Combined species richness for two sites, where $\boldsymbol{a}$ is the number of species in site $\mathbf{A}, \boldsymbol{b}$ is the number of species in site $\mathbf{B}$, and $\mathbf{c}$ is the number of species common to sites $A$ and $B: S_{A B}=a+b-c$.

2. Similarly, the number of species unique to each site is: $\mathrm{U}_{A B}=\mathrm{a}+\mathrm{b}-2 \mathrm{c}$.

This index varies from 0 (both sites are identical in species composition) to 1 (no shared species). The value has a meaning opposite to the similarity, indicating the rate of species turnover or $\beta$ diversity [42-45]. Additionally, we estimated the degree of similarity between pairs of vegetation types by using the Jaccard similarity index [44]. This index also ranges from $0-1$, where higher values indicate lower complementarity. The analysis of species complementarity was modelled using EstimateS V.750 [42], and we calculated the Jaccard's similarity index using BioDiversity Professional V2 [45].

\section{RESULTS}

\subsection{Species Richness in Vegetation Types}

We invested a total of 834 person-hour of sampling effort at sites representing all four vegetation types. A total of 244 individuals of 31 species were recorded (i.e., gamma diversity; Fig 1; Table 1), representing nine families and twenty genera. The family Hylidae was the most diverse (13 species), followed by the Plethodontidae (6), and Bufonidae (4) (Table 2; Fig. 2). In the CF, we found 19 species (alpha diversity) in 12 samples; five species were unique to this vegetation type (Bromeliohyla dendroscarta, Ecnomiohyla miotympanum, Trachycephalus venulosa, Eleutherodactylus nitidus, and Tlalocohyla picta). In the TEF, we found 14 species in 12 samples, four of these species were exclusive to this vegetation type (Bolitoglossa platydactyla, Incilius nebulifer, Scinax staufferi, and Smimiscabaudinii, Table 2; Fig. 2). The POF had the highest number of exclusive species (7, Ambystoma velasci, Chiropterotriton dimidiatus, C. multidentatus, Hyla eximia, $H$. plicata, Plectrohyla robertsorum, and Pseudoeurycea altamontana) out of a total of 13 species. The xeric scrub (XS) had the lowest number of species (6) (Table 1) and thus, the lowest diversity. None was exclusive for this type of vegetation (Table 2; Fig. 2).

Chao1 predicted a higher completeness in species richness in the $\mathrm{CF}$, the POF and the XS, but not in the TEF. 
Table 2. Number amphibians collected in the main vegetation types of Hidalgo state: CF (cloud forest), POF (pine-oak forest), XS (xeric scrub), and TEF (tropical evergreen forest)

\begin{tabular}{|c|c|c|c|c|c|c|}
\hline Class & \multirow{2}{*}{ Species } & \multicolumn{4}{|c|}{ Vegetation types } & \multirow{2}{*}{ Species codes } \\
\hline Family & & $\mathbf{C F}$ & POF & XS & TEF & \\
\hline \multicolumn{7}{|l|}{ AMPHIBIA } \\
\hline \multicolumn{7}{|l|}{ CAUDATA } \\
\hline \multirow[t]{4}{*}{ Plethodontidae } & Bolitoglossa platydactyla & 0 & 0 & 0 & 1 & DI \\
\hline & Chiropterotriton dimidiatus & 0 & 2 & 0 & 0 & $\mathrm{X}$ \\
\hline & C. multidentatus & 0 & 2 & 0 & 0 & $\mathrm{Z}$ \\
\hline & Pseudoeurycea altamontana & 0 & 5 & 0 & 0 & $\mathrm{~W}$ \\
\hline \multicolumn{7}{|l|}{ ANURA } \\
\hline \multirow[t]{4}{*}{ Bufonidae } & Incilius marmoreus & 2 & 0 & 0 & 7 & $\mathrm{~K}$ \\
\hline & I. nebulifer & 0 & 0 & 0 & 1 & $\mathrm{CI}$ \\
\hline & I. valliceps & 7 & 0 & 4 & 15 & $\mathrm{D}$ \\
\hline & Chaunus marinus & 8 & 0 & 0 & 11 & $\mathrm{C}$ \\
\hline Scaphiopodidae & Spea multiplicata & 0 & 2 & 10 & 0 & $\mathrm{Y}$ \\
\hline \multirow[t]{8}{*}{ Hylidae } & Bromeliohyla dendroscarta & 4 & 0 & 0 & 0 & I \\
\hline & Plectrohyla arborescandens & 1 & 0 & 0 & 1 & $\mathrm{R}$ \\
\hline & P. charadricola & 5 & 0 & 0 & 11 & G \\
\hline & P. robertsorum & 0 & 7 & 0 & 0 & $\mathrm{~V}$ \\
\hline & Scinax staufferi & 0 & 0 & 0 & 1 & E1 \\
\hline & Smilisca baudinii & 0 & 0 & 0 & 4 & BI \\
\hline & Tlalocohyla picta & 5 & 0 & 4 & 2 & $\mathrm{H}$ \\
\hline & Trachycephalus venulosa & 6 & 0 & 0 & 0 & $\mathrm{~F}$ \\
\hline Leptodactylidae & Leptodactylus melanonotus & 2 & 0 & 0 & 1 & $\mathrm{~J}$ \\
\hline \multirow[t]{2}{*}{ Craugastoriodae } & Craugastor decoratus & 2 & 0 & 0 & 0 & $\mathrm{~N}$ \\
\hline & C. rhodopis & 12 & 1 & 0 & 2 & A \\
\hline Eleutherodactylidae & Eleutherodactylus nitidus & 2 & 0 & 0 & 0 & $\tilde{\mathrm{N}}$ \\
\hline \multirow[t]{3}{*}{ Ranidae } & Lithobates berlandieri & 6 & 7 & 7 & 13 & $\mathrm{E}$ \\
\hline & L. spectabilis & 1 & 6 & 0 & 0 & $\mathrm{O}$ \\
\hline & Total & 78 & 64 & 31 & 71 & \\
\hline
\end{tabular}



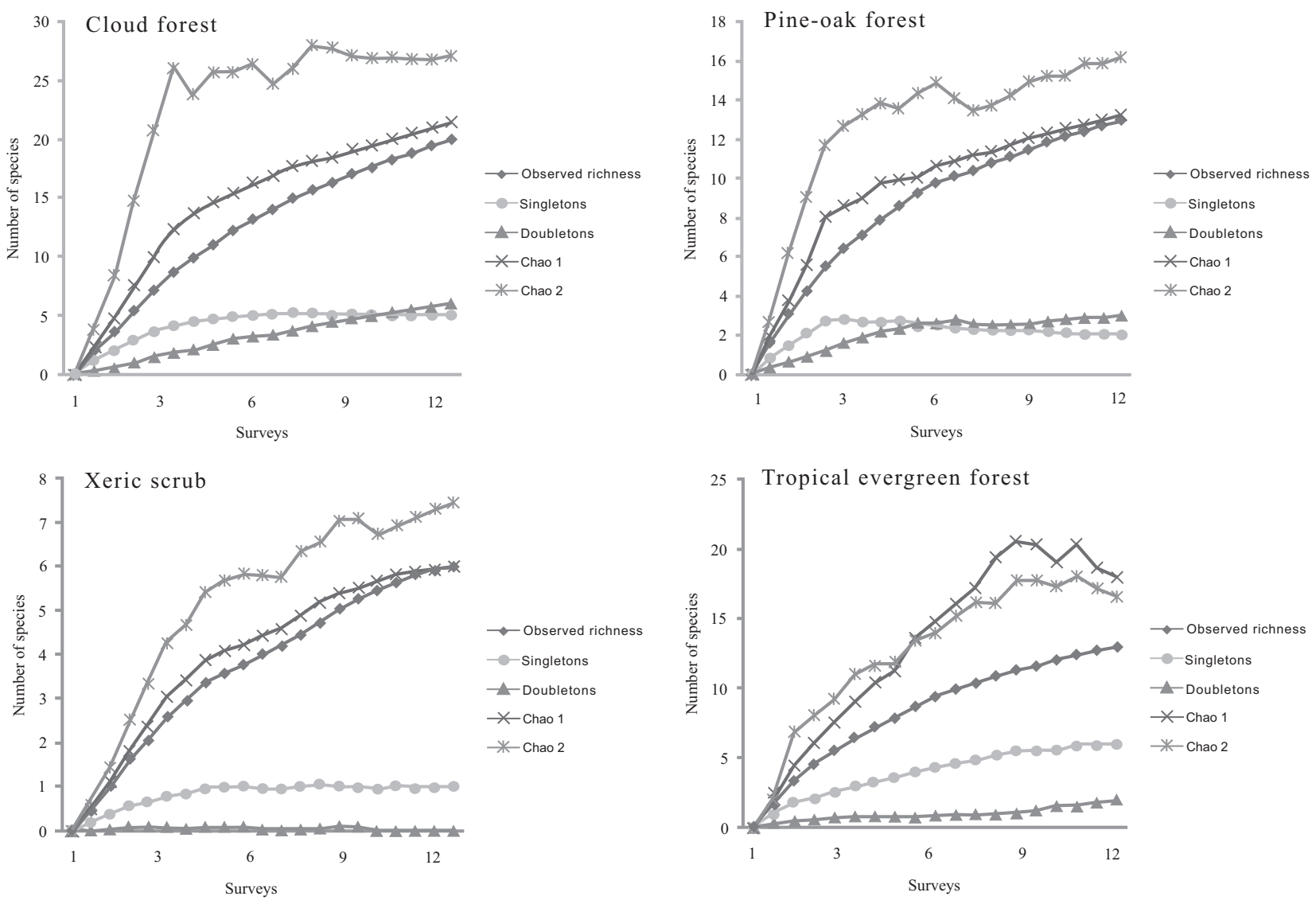

Fig. (2). Amphibian species accumulation curves in the main vegetation types of Hidalgo state. The $\mathrm{Y}$ axis represents the number of species collected and the $\mathrm{X}$ axis represents the number of samplings used in the collection of amphibians.

The observed species richness was higher in $\mathrm{CF}$; however, our estimators predicted that between three $($ Chao1 $=91 \%)$ and eight $($ Chao $2=74 \%)$ amphibian species were not detected in our surveys (Table 2 and $\mathbf{3}$; Fig. 2). The POF exhibited the highest percentage of completeness $($ Chao1 $=$ $100 \%$, Chao2 = 81\%). According to Chao2, it is still necessary to add three to four species (Table 2 and 3; Fig. 2). The TEF is the second in species richness (Table $\mathbf{2}$ and $\mathbf{3}$; Fig. 2) and showed a completeness of 72 and $89 \%$, respectively (Table $\mathbf{2}$ and 3; Fig. 2).

Overall, estimates of completeness were higher in the XS and the POF (Fig. 2; Table 2), particularly in XS (Chao1=
$100 \%$ and Chao $2=86 \%$; Table 2 and 3; Fig. 2). It could be due to the small number of species reported (6) in a relatively large number of samples (12). Overlap between singletons and doubletons curves show when the inventory is almost complete. When there is a complete intersection of these curves, species richness curve is asymptotic. Inventories in the $\mathrm{CF}$ and the POF are close to completion, which is reflected in a asymptotic curve well defined for XS and TEF (Table 2 and 3; Fig. 2).

\subsection{Species Composition in Vegetation Types}

Table 2 and Fig. (3) show the species richness (S) in the CF $(S=19 ; 32 \%)$, the POF $(S=13 ; 26 \%)$, the XS $(S=6 ; 13 \%)$,

Table 3. Comparison of amphibian species richness between pairs of the main vegetation types of Hidalgo: CF (cloud forest), POF (pine-oak forest), XS (xeric scrub), and TEF (tropical evergreen forest)

\begin{tabular}{|c|c|c|c|}
\hline Vegetation types (Observed richness) & Shared species & Complementarity & Similarity (Jaccard index) \\
\hline \hline CF-POF (19-13) & 5 & 0.82 & 0.7 \\
\hline CF-XS (19-6) & 4 & 0.82 & 0.49 \\
\hline CF-TEF (19-14) & 10 & 0.58 & 0.63 \\
\hline POF-XS (13-6) & 2 & 0.88 & 0.38 \\
\hline POF-TEF (13-14) & 3 & 0.87 & 0.56 \\
\hline XS-TEF (6-14) & 2 & 0.89 & 0.51 \\
\hline
\end{tabular}




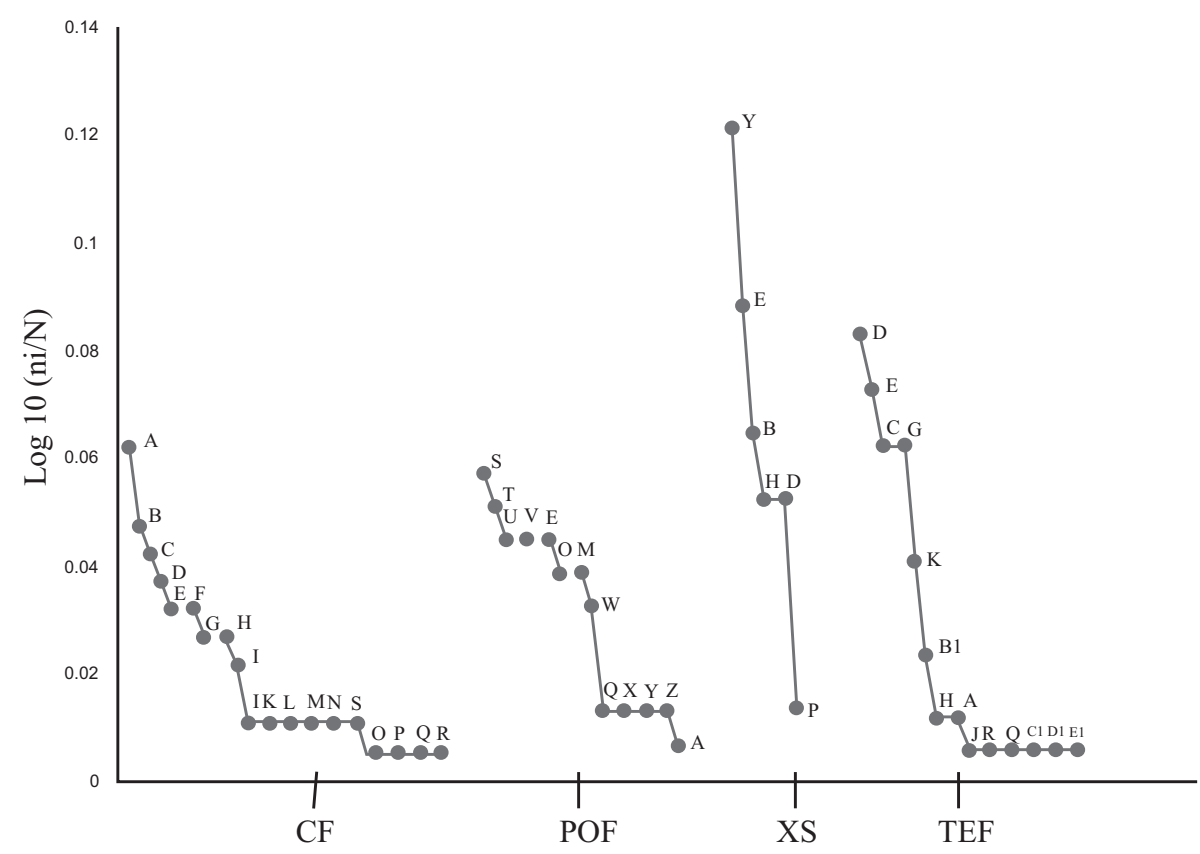

Fig. (3). Rank-abundance curves of amphibian species in the main vegetation types of Hidalgo state. The $\mathrm{Y}$ axis represents the abundance of each species transformed into Log 10, and the X axis groups the species by vegetation type: CF (cloud forest), POF (pine-oak forest), XS (xeric scrub), TEF (tropical evergreen forest). Species codes as shown in Table 2.

and the TEF $(\mathrm{S}=14 ; 29 \%)$. The ranid frog Lithobates berlandieri was the single most abundant species present in all vegetation types.

Rare species mainly occur in the $\mathrm{CF}$, the POF and the TEF (Table 2; Fig. 3). A particular case was Craugastor rhodopis which was dominant in the $\mathrm{CF}$, rare in the POF and infrequent in the TEF (Table 2; Fig. 3). In the POF, Ambystoma velasci, Hyla plicata, and $H$. eximia were the most abundant and exclusive species, while Chiropterotriton dimidiatus, C. multidentatus, Pseudoeurycea bellii, and Spea multiplicata were less abundant or rare. The latter was the only dominant species in XS while Hyla arenicolor was an infrequent species (Table 2; Fig. 3). The most abundant species in TEF were Cranopsis valliceps, Lithobates berlandieri, Chaunus marinus, and Plectrohyla charadricola. This vegetation type held a considerable number of rare species as in the POF (Table 2; Fig. 3).

\subsection{Complementarity}

Complementarity of amphibian diversity was high among vegetation types, evidenced by the high species turnover (beta diversity) (Table 3). All possible pairings of vegetation types yielded greater than $50 \%$ in complementarity. The comparison of the $\mathrm{CF}$ and the TEF showed a low complementarity and a high similarity, which indicates low species turnover or few unique species for each vegetation type $(\mathrm{C}=0.58, I S \hat{j}=0.63$; Table 3$)$.

The highest complementarity was between the TEF and the XS $(\mathrm{C}=0.89$; Table 3$)$, representing a high species turnover. However, the latter had the lowest species richness and only $L$. berlandieri was present in both vegetation types; thus, replacement was close to $100 \%$, in contrast to similarity value $(I S \hat{j}=0.51$; Table 3$)$.

This pattern of high complementarity was very similar to the comparison between the POF and the TEF where complementarity and similarity values were similar, although the abundance of individuals in each vegetation type was completely different (Table $\mathbf{3}$ ).

The value of complementarity in the comparison between the $\mathrm{CF}$ and the POF was $\mathrm{C}=0.82$ and a similarity value of $I S \hat{\jmath}=0.70$ (Table 3). These values were higher when compared to the previous combination (CF and TEF) (Table 3). Low complementarity values mean high similarity values because there are a few exclusive species in each vegetation type, such as between the $\mathrm{CF}$ and the TEF $(\mathrm{C}=0.58, I S \hat{\jmath}=$ 0.63; Table 3). It is important to emphasize that this comparison represents two vegetation types that share ecological characteristics, although they differ in species composition. However, there was not to have a strong difference in the choice of any of these vegetation communities, since similarity and species turnover were very similar (Table 3).

\section{DISCUSSION}

\subsection{Species Composition}

Amphibian diversity in Hidalgo represents $14.5 \%$ and $50 \%$ of the species and family diversity in Mexico, respectively $[2,7]$. This is relevant from the perspective of the biodiversity in Hidalgo. In this study, we found 31 species of amphibians in the four main vegetation types of the state; however, this is likely to be a substantial underestimate of the true diversity of amphibians. Many areas of Hidalgo have not been surveyed exhaustively; therefore, they could hold new species or unrecorded species. For example, recent surveys [7] in remote areas of Hidalgo have revealed several new records of amphibians not previously recorded in the state. Modern taxonomy and studies on systematics of some groups of amphibian species, such as Hylidae are likely to result in the recognition of additional new species. Interestingly, no amphibian species 
is endemic to the state [2,7]. A study by [7] also reported 31 amphibian species in Hidalgo; however, in our study we report species that those authors did not recognized and almost a quarter of the species they reported are currently regarded as subspecies or synonyms of other species [46].

This study shows that a higher amphibian diversity exists in Hidalgo relative to several other Mexican states with similar area (e.g., Aguascalientes [47], Valle de México [12], or even some larger states such as Coahuila [48]). Such diversity could be explained by the occurrence of multiple biogeographic regions in Hidalgo (Sierra Madre Oriental, Transmexican Volcanic Belt, Mexican Plateau and the Gulf of Mexico) and the environmental heterogeneity they produce $[49,50]$. Furthermore, this species richness may also be the result of the heterogeneity of habitats and microhabitats available for different species inhabiting the different vegetation types. This highlights the need to use specific techniques for collecting amphibians in otherwise inaccessible habitats such as the forest canopy [51-53].

\subsection{Comparison of Species Richness by Vegetation Type}

According to [54-57], alpha diversity is the measure of the number of species in a territorial sample that depends on the area for assessing local diversity [58, 59]. Habitat fragmentation leads to the reduction of biodiversity in an area or region, limiting the development of organisms by factors such as resources availability, competition, and predation [58, 60-62] have argued that fragmentation in southwestern Brazil severely damages anuran communities, leading to changes in temperature, precipitation and soil erosion, and therefore a decrease in alpha diversity [41, 63, 64].

The alpha diversity of each vegetation community examined in this study differed, although the POF and the TEF exhibited a similar number of species (13 and 14, respectively; Table 3). The highest species diversity (alpha diversity) was found in the TEF and the lowest in the XS. These differences in species richness could be due to the unique ecological conditions prevailing in each vegetation type. For example, the microclimatic conditions in the $\mathrm{CF}$ are more humid than in the POF and the XS. In the CF there is a higher accumulation of organic matter, greater canopy cover, and a warm-cold temperature constant, requirements necessary for the life of amphibians $[7,65,66]$. Environmental characteristics of the XS, such as high temperatures and low humidity are limiting factors for most amphibian species [67]. However, some species reported in this study have successfully adapted to arid environments, such as Spea multiplicata and Hyla arenicolor, two amphibians characteristic of the XS [12].

A number of authors have found even greater species diversity in the CF of Mexico. For example, [7] reported a greater number of amphibian species in the CF of Hidalgo; however, their sampling effort was significantly larger than ours. Similarly, [58] surveyed patches of CF in Veracruz state. They found five species more than in our study, but their sampling effort was also larger. We note that the CF in Hidalgo is the vegetation community with the highest degree of disturbance, yet was also the vegetation type supporting the highest number of amphibian species. This pattern is similar to another study in a community of frogs in fragments of CF [68].

In the POF we recorded 13 species of amphibians, but other studies have reported different results. For example, [22] recorded only seven of the 13 species reported in this study, although the size of their study area was less extensive. [69] also reported fewer species (six) in this vegetation type, but they recorded two species (Eleutherodactylus longipes and E. verrucipes) not found in our work. This might represent the missing species that Chao2 detected.

\subsection{Abundance Patterns}

Of the four vegetation types studied, the CF held the highest number of species, being the frog Craugastor rhodopis the dominant species, as found in other studies [59]. This species also occurs in the POF and the TEF, but it is rare, suggesting that the $\mathrm{CF}$ constitutes the main habitat for C. rhodopis [68]. Another dominant species in the CF was Trachycephalus venulosa, a species that was not dominant in the POF and the TEF. The composition of rare species in the CF we studied was similar to that found in other studies of anuran communites in fragmented environments of $\mathrm{CF}$ in Veracruz [58], where many of the species are rare or secretive. Some authors [64] have also suggested that comprehensive amphibian surveys in the CF require a larger sampling effort than that in other environments, including the use of specialized sampling techniques in hard-to-access habitats, such as the canopy or bromeliads that are known to harbour many of these amphibians [70, 71].

The TEF was the vegetation type that supported the second highest number of species (14 of 31; Table 2). In this vegetation community, Incilius valliceps, Lithobates berlandieri, Chaunus marinus and Plectrohyla charadricola were the most abundant species. These species have been reported in other localities of Hidalgo and other Mexican states with this vegetation type $[58,72]$. The difference between species in the CF and the TEF is evident; however, these vegetation communities contain the largest number of species, which is probably due to similar environmental conditions prevailing in both vegetation types [65].

\subsection{Complementarity}

Overall, complementarity between vegetation types was high, more than 70\% (Table 3). However, the single lowest level of complementarity in vegetation types was found between the CF and the TEF, showing that there is little heterogeneity in terms of exclusive species composition. In contrast, we found an approximate mean value of $40 \%$ in similarity, showing that in the four vegetation types there are several exclusive or unique species (Table 4). These differences in the values of complementarity and similarity are also seen in other sites with different vegetation types [5, $46,59]$ and in other animal groups [73].

The CF and the TEF share the highest number of species (10), a pattern that could be explained by the presence of similar environmental conditions, such as precipitation and temperature, which are factors that allow the establishment of species [66]. This pattern was previously found in the CF and the TEF of México, these vegetation types have 
relatively homogeneous environmental characteristics, which allow the establishment of a large number of endemic species $[6,12]$.

The high species turnover between vegetation types shown in this study is consistent with that reported by [7476] in different animal groups in Mexico. These authors argue that México is a country with a low alpha diversity but with a high beta diversity. The results of this study follow the same pattern since the values of alpha diversity are not high, but replacement of species with values close to $90 \%$ show a high beta diversity.

Beta diversity is a powerful tool that measures species turnover based on unique species in a site, region or landscape [56]. This tool is used in biogeographic studies to generate results that better explain the choice and design of protected natural areas. For example, [8] modelled the distribution of amphibians and reptiles in order to locate areas with high diversity in Hidalgo, by using diversity indexes and biogeographical data. The use of statistical tools (analysis of diversity) as well as methods used in historical biogeography (PAE) can substantially help us to evaluate protected areas [49]. Even though the use of different methodologies (species richness and biogeography) can locate areas with high species richness, this approach has so far been poorly used to the urgent need to preserve areas with significant numbers of species in some category of conservation risk (e.g., endemics with restricted distribution). It is fundamental that the design and implementation of conservation strategies should be based on the use of various tools such as diversity indexes and biogeographical tools at different scales, since this would allow us to have a broader view of the conservation status of amphibians and reptiles, and of other groups occurring in different environments of Hidalgo and México.

\section{CONCLUSIONS}

Hidalgo has a high amphibian diversity with 31 species distributed in 20 genera and 7 families, even thought it is located in central México with a large proportion of arid environments. This species richness coincides with the number of species reported by $[34,77]$ for the state, but we also found species not mentioned by these authors.

Our results suggest that future surveys should apply a greater sampling effort in each vegetation type, because our diversity estimators indicated that none of these four vegetations types had complete inventories. The highest recorded number of species was in the CF with 19, followed by the TEF (14), the POF (13), and the XS (6). In the POF we recorded the highest number of exclusive species (seven), followed by the CF (five), and the TEF (four).

Amphibian communities are dominated mostly by rare or uncommon species. Lithobates berlandieri was the only abundant species in all vegetation types studied. In the CF, Craugastor rhodopis was the most abundant species, but this species was rare in the POF and the TEF.

Beta diversity or complementarity was $80 \%$ in most of the comparisons; however, in the comparison between the $\mathrm{CF}$ and the TEF, we found a low value of complementarity and a high value of similarity, indicating that the amphibian species in these two vegetation types are similar.

\section{ACKNOWLEDGEMENTS}

We thank Barry P. Stephenson for his comments on the manuscript. We also thank Claudia E. Moreno for helping in the data analysis. To A. Ramírez Pérez, V. D. Vite Silva, R. Hernández Jiménez for their help during fieldwork. To M. A. Martínez-Morales for his great help in reading this manuscript. This research was supported by projects: SEPPROMEP 1103.5/03/1130, SEP-PROMEP/103.5/04/2751, CONACYT-S52552-Q and FOMIX-CONACYT-43761 y 95828 .

\section{CONFLICT OF INTEREST}

None declared.

\section{REFERENCES}

[1] Espinosa-Organista D, Ocegueda-Cruz, S, Aguilar-Zúñiga C, Flores-Villela O, Llorente-Bousquets J. In: Soberon J, Halffter G, Llorente-Bousquets J, Eds. Capital natural de México, Vol. I: Conocimiento actual de la biodiversidad. Comisión Nacional para el Uso y Conocimiento de la Biodiversidad. México, D. F. 2008 pp. 33-65.

[2] Ramírez-Bautista A, Canseco-Márquez L, Mendoza-Quijano F. Inventarios herpetofaunísticos de México: Avances en el conocimiento de su biodiversidad. No. 3. México D.F: Publicación Especial de la Sociedad Herpetológica Mexicana 2006.

[3] CONABIO. Capital natural de México, Vol. I: Conocimiento actual de la biodiversidad. Comisión Nacional para el Conocimiento y Uso de la Biodiversidad, México. México D.F 2008.

[4] Mittermeier RA. In: Wilson EO, Ed. Biodiversity. Washington D.C.: National Academy Press 1998; pp. 145-54.

[5] Ochoa-Ochoa LM, Flores-Villela OA. Áreas de diversidad y endemismo de la herpetofauna mexicana. Universidad Nacional Autónoma de México, Comisión Nacional para el Conocimiento y Uso de la Biodiversidad. México, D.F 2006.

[6] Flores-Villela OA. In: Ramamoorthy T P, Bye R, Lot A, Fa J, Eds. Diversidad Biológica de México, Orígenes y Distribución. Instituto de Biología. Universidad nacional Autónoma de México, D.F. 1998 pp. 225-78.

[7] Mendoza-Quijano F, Quijano-Manilla G, Mendoza-Paz RF. In: Ramírez-Bautista A, Canseco-Márquez L, Mendoza-Quijano F Eds. Inventarios herpetofaunísticos de México: Avances en el conocimiento de su biodiversidad. Publicación Especial de la Sociedad Herpetológica Mexicana No. 3, México D.F. 2006; pp. 99-109.

[8] Hernández-Salinas U. Estudio herpetofaunístico del estado de Hidalgo. Tesis de Maestría. México: Universidad Autónoma del Estado de Hidalgo 2009.

[9] Lips KR. Decline of a tropical amphibian fauna. Conserv Biol 1998; 12: 106-17.

[10] Stuart SN, Chanson J, Cox NA, Young B, Rodriguez AS. Status and trends of amphibian declines and extinctions worldwide. Science 2004; 306: 1783-6.

[11] Naranjo EJ, Dirzo R, López-Acosta JC, Rendón-Von OJ, Reuter A, Sosa-Nishizaki O. In: Dirzo R, González R, March IJ, Eds. Comp. Capital Natural de México, Volumen. II: Estado de conservación y tendencias de cambio. México, D.F: Comisión Nacional para el Conocimiento y Uso de la Biodiversidad 2009; pp. 247-76.

[12] Ramírez-Bautista A, Hernández-Salinas U, García-Vázquez UO, Leyte-Manrique A, Canseco-Márquez L. Herpetofauna del Valle de México: Diversidad y conservación. Comisión Nacional para el Uso y Conocimiento de la Biodiversidad. México: Universidad Autónoma del Estado de Hidalgo 2009.

[13] Lips KR, Reeve J, Witters LR. Ecological factors predicting amphibian population declines in Central America. Conserv Biol 2003; 17: 1078-88.

[14] Lips KR, Mendelson III JR, Muñoz-Alonso A, Canseco-Márquez L, Mulcahy DG. Amphibians populations decline in montane southern Mexico: resurveys of historical localities. Biol Conserv 2004; 119: 555-564.

[15] Pough FH, Andrews RM, Cadle JE, Crump ML, Savitzky AH, Wells KD. Herpetology. $2^{\text {nd }}$ ed. New Jersey, USA: Prentice Hall 2001 . 
[16] Mendelson III JR, Lips KR, Gagliardo RW, et al. Confronting amphibian declines and extinctions. Science 2006; 313: 48.

[17] Lips KR, Burrowes PA, Mendelson III JR, Parra-Olea G. Amphibian declines in Latin America: widespread population declines, extinctions and impacts. Biotropica 2005; 37:163-5.

[18] Lips KR, Brem F, Brenes R, et al. Infectious disease and global biodiversity loss: pathogens and enigmatic amphibian extinctions. Proc Natl Acad Sci USA 2006; 103: 3165-70.

[19] Lips KR. Mass mortality and population declines of anurans at an upland site in Western Panama. Conserv Biol 1999; 13: 117-25.

[20] Regester KJ, Whiles MR, Lips KR. Variation in the trophic basis of production and energy flow associated with emergence of larval salamander assemblages (Ambystomatidae) from forest ponds. Freshw Biol 2008; 53: 1754-67.

[21] Lips KR, Diffendorfer J, Mendelson III JR, Sears MW. Riding the wave: reconciling the roles of disease and climate change in amphibian declines. PLoS (Public Library of Science) Biology 2008; 6: 441-54.

[22] Ramírez-Bautista A, Ramírez-Pérez A. Sabes quien vive en el Parque Nacional El Chico? Anfibios y reptiles. Universidad Autónoma del Estado de Hidalgo. El Chico, Pachuca, Hidalgo. México: Secretaria de Educación Pública 2008.

[23] Vite-Silva VD, Ramírez-Bautista A, Hernández-Salinas U, Diversidad de anfibios y reptiles de la Reserva de la Biosfera Barranca de Metztitlán, Hidalgo, México. Revista Mexicana de Biodiversidad 2010; 80: 473-85.

[24] INEGI. Síntesis geográfica del estado de Hidalgo. Instituto Nacional de Estadística, Geografía e Informática. Edificio sede, Aguascalientes, Aguascalientes. México 1992.

[25] Rzedowski J. Vegetación de México. Limusa, México. D.F: 1981.

[26] Luna-Vega I, Alcántara O, Espinosa-Organista D, Morrone JJ. Historical relationships of the Mexican cloud forests: A preliminary vicariance model applying parsimony analysis of endemicity to vascular plant taxa. J Biogeogr 1999; 26: 1299-1305.

[27] Williams-Linera G. Tree species richness complementarity, disturbance and fragmentation in a Mexican tropical montane cloud forest. Biodivers Conserv 2002; 11: 1825-43.

[28] Pineda E, Moreno C, Escobar F, Halffter G. Frog, bat and dung beetle diversity in the cloud forest and coffee agrosystems of Veracruz, Mexico. Conserv Biol 2005; 19: 400-10.

[29] Pavon NP, Mesa Sánchez M. Cambio climatico en el estado de Hidalgo: Clasificasión y tendencias climáticas. Universidad Autónoma del Estado de Hidalgo 2009.

[30] Nolasco M. Café y sociedad en México. Centro de Ecodesarrollo. México D.F. 1985.

[31] Whittaker RH. Vegetation of the siskiyou mountains, Oregon and California. Ecol Monogr 1960; 30: 279-338.

[32] Whittaker RH. Evolution and measurement of species diversity. Taxon 1972; 21: 213-51.

[33] Halffter G, Moreno CE. In: Halffter G, Soberon J, Koleff P, Melec A, Eds. Sobre Diversidad Biológica: El significado de las diversidades. Sociedad Entomologica Aragoneza (SEA). Comisión Nacional para el Conocimiento y Uso de la Biodoversidad, México. Grupo Diversitas-México. Consejo Nacional de Ciencia y Tecnología (CONACyT), México, D. F. 2005; pp. 5-18.

[34] Smith HM, Taylor EH. Annotated checklist and keys to the amphibians and reptiles. A Reprint of Bulletins 187, 194 and 199. Eric Lundberg, Ashton, Maryland 1966.

[35] Smith HM, Taylor HS. Anannotated checklist and key to the Amphibia of Mexico. Bull U.S. Natl Museum 1948; 194: 1-118.

[36] Campbell JA, Frost DR. Anguid lizard of the genus Abronia: revisionary notes, descriptions of for new species, a phylogenetic analisis, and key. Bull Am Mus Nat Hist 1993; 216, 1-121.

[37] Duellman WE. The hylid frogs of Middle America. Museum of Natural History. The Society For the Study of Amphibians and Reptiles. Kansas, USA 2001.

[38] Frost DR, Grant T, Faivovich J, et al. The amphibian tree of life. Bull Am Mus Nat Hist 2006; 297, 1-370.

[39] Frost DR, Grant T, Faivovich J, et al. Is The Amphibian tree of life really fatally flawed? Cladistics 2008; 24, 385-95.

[40] Wittaker RJ, Willin KJ, Field R. Scale and species richness: Toward a general, hierarchical theory of species diversity. J Biogeogr 2001; 28: 453-70.

[41] Pianka ER. Latitudinal gradients in species diversity: a review of the concepts. Am Nat 1966; 100: 36-40.
[42] Colwell RK. Estimates: Statistical estimation of species richness and shared species from samples. Version 7.5: 2005 [Cited 2007 Sep 2]. Available from: http://purl.oclc.org./estimates

[43] Colwell R, Coddington J. Estimating terrestrial biodiversity trough extrapolation. Philos Trans R Soc Lond Ser 1994; 345: 110-8.

[44] Chao A. Estimating population size for sparse data in capturerecapture experiments. Biometrics 1989; 45: 427-38.

[45] Magurran A. Ecological biodiversity and its measurement. $1^{\text {st }}$ ed. New York. USA: Princenton University Press 1998.

[46] Ramírez-Bautista A, Moreno CE. In: Ramírez-Bautista A, Canseco-Márquez L, Mendoza-Quijano F, Eds. Inventarios herpetofaunísticos de México: Avances en el conocimiento de su biodiversidad. México D.F. Publicación Especial de la Sociedad Herpetológica Mexicana No. 3 2006; pp. 74-98.

[47] Vázquez-Díaz J, Quintero-Díaz GE. Anfibios y reptiles de Aguascalientes, $2^{\text {nd }}$ ed. Comisión Nacional para el Conocimiento y Uso de la Biodiversidad. Centro de Investigaciones y Estudios Multidisciplinarios de Aguascalientes. México: Aguascalientes 2005.

[48] Lemos-Espinal JA, Smith HM. Anfibios y reptiles del estado de Coahuila, México. Universidad Nacional Autónoma de México, University of Colorado at Boulder, Comisión Nacional para el Conocimiento y Uso de la Biodiversidad. México D.F 2008.

[49] Morrone JJ, Márquez J. Biodiversity of mexican terrestrial arthropods (Arachnida and Hexapoda): A biogeographical Puzzle. Acta Zool Mex (Nueva Serie) 2008; 24: 15-41.

[50] Campbell JA, Frost DR. Anguid lizard of the genus Abronia: revisionary notes, descriptions of for new species, a phylogenetic analysis and key. Bull Am Mus Nat Hist 1993; 216: 1-121.

[51] Duellman WE. The hylid frogs of Middle America. Museum of Natural History. Vol. I. The Society For the Study of Amphibians and Reptiles. Kansas. USA 2001.

[52] Frost DR, Grant T, Faivovich J, et al. The amphibian tree of life. Bull Am Mus Nat Hist 2006; 297: 1-370.

[53] Duellman WE. Temporal fluctuation in abundances of anuran amphibians in a seasonal Amazonian rainforest. J Herpetol 1995; 29: 13-21.

[54] Whittaker RH. Vegetation of the siskiyou mountains, Oregon and California. Ecol Monogr 1960; 30: 279-338.

[55] Whittaker RH. Evolution and measurement of species diversity. Taxon 1972; 21: 213-51.

[56] Halffter G, Moreno CE. In: Halffter G, Soberon J, Koleff P, Melec A, Eds. Sobre diversidad biológica: El significado de las diversidades. Sociedad Entomologica Aragoneza (SEA). Comisión Nacional para el Conocimiento y Uso de la Biodoversidad, México. Grupo Diversitas-México. México, D. F.: Consejo Nacional de Ciencia y Tecnología (CONACyT) 2005; pp. 5-18.

[57] Halffter G. A strategy for measuring landscape biodiversity. Biol Inter 1998; 36: 3-17.

[58] Pineda E, Moreno C, Escobar F, Halffter G. Frog, bat and dung beetle diversity in the cloud forest and coffee agrosystems of Veracruz, Mexico. Conserv Biol 2005; 19: 400-10.

[59] Urbina-Cardona J, Olivares-Pérez M, Hugo-Reynoso V. Herpetofauna diversity and microenvironment correlates across a pasture edge interior ecotone in tropical rainforest fragments in the Los Tuxtlas Biosphere Reserve of Veracruz, México. Biol Conserv 2006; 132: 61-75.

[60] Pineda E, Halffter G. In: Halffter G, Soberon J, Koleff P, Melec A, Eds. Sobre diversidad biológica: El significado de las diversidades. alfa, beta y gama. 3m Monografías 3er Milenio, Vol. 4. Sociedad Entomológica Aragonesa. Comisión Nacional para el Conocimiento y Uso de la Biodiversidad. Grupo Diversitas y Consejo Nacional de Ciencia y Tecnología, Zaragoza. España. 2005; pp. 165-76.

[61] Calderon-Mandujano R, Galindo-Leal C, Cedeño-Vázquez JR. Utilización de hábitat por reptiles en estados sucecionales de la selva estacional de Campeche, México. Acta Zoológica Mexicana (Nueva Serie) 2008; 24: 95-114.

[62] Cabral-Eterovick P, Sazima I. Structure of an anuran community in a montane meadow in southeastern Brazil: effects of seasonality, hábitat, and predation. Amphib-Reptil 2000; 21, 439-61.

[63] Lee JC. The amphibians and reptiles of the Yucatan Peninsula. New York, USA: Cornell University Press, Ithaca 1996.

[64] Lynch JD, Myers WC. Frogs of the fitzingeri group of Eleuterodatylus in eastern Panama and Chocoan South America (Leptodactylidae). Bull Am Mus Nat Hist 1983; 175: 481-572. 
[65] Williams-Linera G. Tree species richness complementarity, disturbance and fragmentation in a Mexican tropical montane cloud forest. Biodivers Conserv 2002; 11: 1825-43.

[66] Nolasco M. Café y sociedad en México. México D.F: Centro de Ecodesarrollo 1985.

[67] Sánchez O. In: Sánchez O, Vázquez-Domínguez E, Eds. Diplomado en manejo de vida silvestre. Conservación y manejo de vertebrados del norte árido y semiárido de México. CONABIO, DGVS-INE (SEMARNAP), U.S. Fish \& Wildlife Service y Facultad de Ciencias Forestales, Universidad Autónoma de Nuevo León. México D. F. 1999; pp. 13-23.

[68] Pineda E, Halffter G. Species diversity and habitat fragmentation: frog in a tropical montane landscape in Mexico. Biol Conserv 2004; 117: 499-508.

[69] Huitzil-Mendoza JC. Herpetofauna de dos localidades en la región norte de Zimapán, Hidalgo. Tesis de Licenciatura. México: Universidad Autónoma del Estado de Hidalgo 2008.

[70] Wilson LD, McCraine JR. The herpetofauna of the cloud forest in Honduras. Amphib Reptile Conserv 2003; 3: 34-48.

[71] Feinsinger P. El diseño de estudios de campo para la conservación de la biodiversidad. Bolivia: Editorial FAN, Santa Cruz de la Sierra. 2003.
Flores-Villela OA, Canseco-Márquez L. Nuevas especies y cambios taxonómicos para la herpetofauna de México. Acta Zoológica Mexicana (Nueva serie) 2004; 20: 115-44.

[73] Lynch SF, Wake DB. Two new species of Pseudoeurycea (Amphibia: Caudata) from Oaxaca, Mexico. Natural History Museum of Los Angeles County: Contrib Sci 1989; 411: 11-22.

[74] Arita HT. In: Medellín RA, Ceballos G, Eds. Avances en el estudio de los mamíferos de México. Asociación Mexicana de Mastozoología, A. C. México D.F. 1993; pp. 109-128.

[75] Scott JH, Norse EA, Arita H, et al. In: Soulé ME, Terborgh J, Eds. Continental conservation, scientific foundations of regional reserve networks. Washington D.C. USA: Island Press 1999; pp. 19-37.

[76] Arita HT, Rodríguez P. In: Llorente-Bousquets J, Morrone JJ, Eds. Introducción a la biogeografía en Latinoamérica: Teorías, conceptos, métodos y aplicaciones. Comisión Nacional para el Conocimiento y Uso de la Biodiversidad, Universidad Nacional Autónoma de México. México D.F. 2001; pp. 63-80.

[77] Wilson LD, Townsend JH, Jhonson JD. Conservation of Mesoamerican Amphibians and reptiles. Eagle Mountain, Utah: Eagle Mountain Publishing, LC 2010.

(C) Hernández-Salinas and Ramírez-Bautista; Licensee Bentham Open.

This is an open access article licensed under the terms of the Creative Commons Attribution Non-Commercial License (http://creativecommons.org/licenses/by-nc/3.0/) which permits unrestricted, non-commercial use, distribution and reproduction in any medium, provided the work is properly cited. 